\title{
PEMBENTUKAN MORALITAS SISWA
}

\author{
Tomas Sialana \\ Sekolah Tinggi Agama Kristen Protestan Negeri Ambon \\ tomassialana4@gmail.com
}

\begin{abstract}
Morality or morality is the doctrine of the Good, the bad that is generally accepted concerning deeds, attitudes, and obligations. SMP Negeri 6 Ambon is a school in the category of excellent schools but there are still students who have moral not good at communicating and behave with teachers and friends such as: like to remove the words of diatribe or in the local language Called Bamaki, the attitude and intonation of the voice of the students, in speaking with the teacher in the school is not polite, anyone uploading pornographic pictures of even pornographic videos, it is very bad impact on the moral and future of the students.

The purpose of this writing is to know and give good understanding to the school, parents, church, to the moral reality of SMP Negeri 6 Ambon, and the importance of the role of teachers in schools, parents, and the church in shaping Good student moral.

In this study using Rahmad's theory. This research uses a qualitative approach. And the method used in this research is qualitative.

From the research shows that, the establishment of student morality is an effort made by certain parties in shaping the moral of poor students into good moral. Another fact that the authors find is, that the school in the category (the Superior school) is not all students who are in the school institution, have good morality, that is in accordance with the vision and mission or purpose of the school institution. The morality of a good student can not be seen from the intelligence and achievements that the students have because, the savvy student is not necessarily moral either. Responsibility to form the moral of students is not only done by teachers, but parents, church and community also involved in carrying out his role. But the fact shows that parents, churches and communities are not maximized in carrying out their role in regards to the intended thing.
\end{abstract}

Keyword: student morality

\section{Pengantar}

(Barnawi dan M. Arifin 2014) Globalisasi telah membawa dampak luas dibelahan bumi mana pun, tak terkecuali di negara Indonesia. Dampak globalisasi ini ada yang positif ada juga yang negatif. Dampak positif dari globalisasi, sebagai berikut: meningkatkan semangat kerja, suka bekerja keras, mempunyai jiwa kemandirian yang baik. Kemajuan teknologi menyebabkan kehidupan bersaing di tingkat kehidupan yang lebih baik. Teknologi di bidang komunikasi, informasi, dan transportasi yang memudahkan kehidupan manusia, cepat dalam bepergian ke suatu tempat, mudah mendapat informasi dan ilmu pengetahuan. Dampak positif dari globalisasi ini sangat baik untuk ditiru oleh para remaja saat ini. Beberapa di antaranya; remaja akan lebih mudah mendapatkan informasi yang terkait dengan perkembangan pendidikan dan perkembangan lainnya, remaja akan lebih cepat berkembang dalam menghadapi teknologi yang terus berkembang, serta pengetahuan dan bekal untuk membedakan dan memilih mana yang baik dan mana yang tidak baik.
Selain dampak positif, globalisasi juga memberikan dampak negatif. Dampak negatif dari globalisasi tersebut di antaranya adalah semakin mudahnya nilai-nilai Barat masuk ke Indonesia yang banyak ditiru oleh masyarakat sehingga hilangnya etika, moral, nilai-nilai budaya dan norma-norma kesopanan, mengabaikan nilai-nilai agama. Semua hal negatif tersebut berujung pada hilangnya karakter bangsa Indonesia. Dampak negatif dari arus globalisasi yang terlihat cemas, adalah perubahan yang cenderung mengarah pada krisis moralitas atau moral dan perilaku para siswa, sehingga menimbulkan sejumlah permasalahan melanda negeri ini. Dapat dicontohkan mulai dari hal kecil seperti, anak-anak sekolah yang membolos pada jam pelajaran, tidak menghargai orang tua di rumah, dan guru di sekolah, dan lain sebagainya. untuk itulah urgensi pendidikan di Indonesia, harus ditingkatkan kualitasnya, untuk mengatasi permasalahan moral pada siswa, dengan lebih mengutamakan pendidikan moralitas pada siswa yang tidak lain adalah sang generasi penerus bangsa.

SMP Negeri 6 Ambon jika dilihat dari kualitas lembaga pendidikan dan kualitas siswa, 
Tomas Sialana

sebagian besar siswa di lembaga ini, memiliki kecerdasan dan kelebihan tersendiri yang mampu membawa mereka pada tingkat prestasi yang baik entah itu di tingkat Kota Ambon, Provinsi, dan di tingkat Nasional. Namun ketika ditelesuri dari segi moralitas, ternyata masih ada siswa SMP Negeri 6 Ambon, yang mempunyai moral yang kurang baik, dalam berkomunikasi antara siswa dengan siswa di sekolah ini mereka banyak mengeluarkan kata-kata kotor, yang dalam bahasa lokal dikatakan (bamaki/mengeluarkan kata-kata yang tidak baik) entah sengaja maupun tidak sengaja, siswa tidak merasa takut dalam mengeluarkan kata-kata cacian. Tindakan siswa ini sudah ditangani lewat pembinaan oleh guru kesiswaan dan guru agama, memberikan konseling kepada siswa tersrbut. Pihak sekolah memanfaatkan waktu ibadah OSIS untuk membina dan mengarahkan siswa secara menyeluruh untuk tidak melakukan hal-hal yang tidak baik, selain itu pihak sekolah juga bekerja sama dengan Gereja untuk mengadakan kegiatan rohani dalam membentuk iman dan moralitas siswa kearah yang baik. Namun perilaku ini masih nampak ketika seorang siswa mengalami permasalahan dengan siswa. Hal ini membuktikan bahwa moralitas sebagian siswa SMP Negeri 6 Ambon masih bermasalah.

Moralitas siswa dalam hal berkomunikasi juga dirasakan oleh para guru dan orang lain yang ada di lingkungan sekolah tersebut. Sering siswa berbicara dengan para guru yang ada di sekolah, tidak mencerminkan suatu sikap dan cara berbicara yang selayaknya hubungan atau kedudukan siswa dan guru. Mestinya seorang siswa yang tahu etika/sopan-santun, di sekolah itu haruslah menghargai gurunya. Siswa-siswi ini sering berbicara dengan guru dengan intonasi suara yang kuat, menjawab pertanyaan-pertanyaan dari guru tersebut dengan sikap yang tidak sopan dan menganggap remeh ketika sedang berbicara dengan guru. Perilaku siswa seperti ini sangat membawa dampak negatif terhadap proses belajarmengajar siswa di kelas. Ketika guru sedang menyampaikan materi pembelajaran siswa sering membuat keributan dalam kelas dengan berbagai macam cara dan alasan yang mereka bisa buat diantaranya; (1) suka mengganggu teman yang ada konsentrasi dalam mengikuti proses belajar. (2) bercerita dan mengejek atau menghina teman yang lain, sehigga siswa tersebut merasa terganggu dalam prosespembelajaran. (3) Sering terjadi perkelahian antara siswa dengan siswa yang lain dalam kelas sehingga terjadi adu fisik dan menimbulkan cacian atau dalam bahasa lokal mengatakan (bamaki / mengeluarkan kata-kata yang tidak baik) tanpa menghargai guru yang ada dalam kelas, yang sementara melakukan proses pembelajaran dan jumlah siswa SMP Negeri 6 Ambon yang moralitasnya tidak baik sebayak 67 orang.

Mencermati perilaku-perilaku siswa atas, maka peneliti merasa tertantang untuk melakukan penelitian mendalam untuk mengetahui pembentukan moral siswa di SMP Negeri 6 Ambon.

\section{Tijauan Literatur}

\subsection{Pengertian Moral}

(Dalam KBBI 1996) Moral diartikan sebagai keadaan baik dan buruk yang diterima secara umum mengenai perbuatan, sikap, kewajiban, budi pekerti dan susila.

Moral juga berarti kondisi mental yang terungkap dalam bentuk perbuatan, selain itu moral berarti sebagai ajaran Kesusilaan (Rahmad, tahun 2014). Kata moral sendiri berasal dari bahasa Latin "mores" yang berarti tata cara dalam kehidupan, adat istiadat dan kebiasaan. Dengan demikian pengertian moral dapat dipahami dengan mengklasifikasikannya sebagai berikut :

a) Moral sebagai ajaran kesusilaan, berarti segala sesuatu yang berhubungan dengan tuntutan untuk melakukan perbuatanperbuatan baik dan meninggalkan perbuatan jelek yang bertentangan dengan ketentuan yang berlaku dalam suatu masyarakat.

b) Moral sebagai aturan, berarti ketentuan yang digunakan oleh masyarakat untuk menilai perbuatan seseorang apakah termasuk baik atau sebaliknya buruk.

c) Moral sebagai gejala kejiwaan yang timbul dalam bentuk perbuatan, seperti berani, jujur, sabar, gairah dan sebagainya.

\subsection{Faktor-faktor yang mempengaruhi moralitas}

(Rahmad 2014) Setiap manusia dalam hidupnya pasti mengalami perubahan atau perkembangan, baik perubahan yang bersifat nyata atau yang menyangkut perubahan fisik, maupun perubahan yang bersifat abstrak atau perubahan yang berhubungan dengan aspek psikologis. Perubahan tersebut dipengaruhi oleh beberapa faktor, baik yang berasal dari dalam manusia (internal) atau yang berasal dari luar (eksternal). 
Faktor-faktor itulah yang akan menentukan apakah proses perubahan manusia mengarah pada hal-hal yang bersifat positif atau sebaliknya mengarah pada perubahan yang bersifat negatif.

Kaitannya dengan pembentukan moral, maka proses pembentukan moral, tidak lain berbicara tentang salah satu aspek perubahan atau perkembangan manusia. Tentu dalam pembentukan moral ada beberapa faktor yang mempengaruhi seperti halnya, perubahan manusia pada umumnya. Menurut beberapa ahli pendidikan, perubahan manusia atau yang lebih spesifik mengenai pembentukan moral dipengaruhi oleh faktor internal dan eksternal. Namun, mereka berbeda pendapat dalam hal faktor mana yang paling dominant mempengaruhi proses perubahan tersebut. Perbedaan tersebut, diakibatkan karena berbedanya sudut pandang atau pendekatan yang digunakan oleh masing-masing tokoh. Dalam beberapa literatur pendidikan terdapat aliran-aliran yang biasa digunakan oleh beberapa ahli pendidikan sebagai suatu pendekatan dalam menilai faktor-faktor yang pengaruhi, proses perubahan atau perkembangan manusia.

Aliran tersebut adalah Aliran Nativisme, Nativisme adalah suatu doktrin filosofis yang berpengaruh besar dalam pemikiran psikologis. Tokoh utamanya Arthur Schopenhaur (1788-1860) seorang filosuf berkebangsaan Jerman (Rahmad, 2014). Aliran ini berpandangan bahwa yang mempengaruhi. Perkembangan manusia adalah faktor keturunan dan pembawaan atau sifat-sifat yang dibawanya sejak lahir. Pendidikan dan pengalaman hidup lainnya tidak dapat mengubah sifat-sifat keturunan atau pembawaaan manusia.

Perkataan moral berasal dari bahasa latin Mores. Mores berasal kata mos yang berarti kesusilaan, tabiat atau kelakuan. Moral dengan demikian dapat diartikan ajaran kesusilaan. Moralitas berarti hal mengenai kesusilaan. Ada perkataan lain yang mengunkapkan kesusilaan yaitu etika. Perkataan etika berasal dari bahasa Yunani: ethos dan ethikos yang berarti kesusilaan, perasaan bating, kecenderungan untuk melakukan sesuatu perbuatan.

Dari beberapa keterangan tersebut dapat ditarik kesimpulan bahwa moral mempunyai pengertian yang sama dengan kesusilaan, memuat ajaran tentang baik buruknya perbuatan. Jadi perbuatan itu dinilai sebagai perbuatan yang baik atau perbuatan yang buruk. Memberikan penilaian atas perbuatan dapat disebut memberikan penilaian etis atau moral. Salah satu cabang dari Psikologi, yaitu Psikologi Perkembangan mengajakan bahwa pada umumya anak yang normal akan mengalami perkembangan mental atau moral. Contoh anak yang sudah berusia 6-7 tahun, sudah sanggup menangkap, mengerti apa yang diucapkan oleh orang lain. Dalam usia itu sudah timbul keinginan untuk belajar, mau mengatahui apa yang selama ini masih gelap baginya. Pada usia ini anak sudah dapat merasakan, bahwa tidak berbusana di muka orang lain itu tidak pantas, ada rasa malu kalau ambil barang milik orang lain itu tidak baik, mencuri namanya. Bila anak sudah mempunyai moral seperti itu adalah sebagai tanda bahwa anak tersebut memiliki moral yang normal. Sebaliknya bila ada seseorang dalam usia yang lebih lanjut atau dewasa, tidak merasa malu apabila tidak berbusana di muka orang lain, itu adalah suatu pertanda bahwa orang yang bersangkutan sangat mundur dari moral. Dalam istilah etika biasanya digunakan kata: amoral, perbuatan yang melampaui batas, melanggar norma kesopanan umum, biasanya diberikan nama dengan istilah "'immoral' moral langsung mempunyai hubungan dengan perbuatan manusia sehari-hari, mempunyai hubungan langsung bagaimana manusia harus berbuat dalam hidupnya sehari-hari, maka dengan itu ilmu moral langsung berhubungan dengan pelaksanaan perbuatan-perbuatan insani, dari itu langsung mempunyai hubungan dengan praktis, maka moral adalah ilmu yang praktis. Disamping itu moral masih tetap bermutu ilmu karena mencari hukum-hukum atau dasar-dasar bagaimana manusia harus berbuat menurut aturan yang dimilikinya.

Fungsi Ilmu Moral, sebagai suatu ilmu yang langsung berguna dalam pergaulan hidup sehari-hari. Etika juga dapat menjadi asas dan menjiwai norma-norma dalam kehidupan, sekaligus memberikan penilaian terhadap corak perbuatan seseorang sebagai manusia.

\subsection{Karakteristik Anak Usia 12-14 Tahun.}

Perkembangan Psikologi Remaja tentu tak lepas dari perkembangan psikologis remaja, yang mana dapat dikatakan suatu proses perkembangan yang dialami seseorang ketika memasuki usia 1222 tahun. Pada proses perkembangan psikologi remaja, anak harus mampu meninggalkan sifat kekanak-kanakannya. Lebih lanjut tentang psikologi remaja awal. Menurut Sri Rumini \& Siti Sundari (2004:53) masa remaja adalah 
peralihan dari masa anak ke masa dewasa yang mengalami perkembangan semua aspek yang berfungsi untuk memasuki masa dewasa. Rentang waktu usia remaja ini biasanya dibedakan atas dua, yaitu $12-15$ tahun=masa remaja awal, 15-18 tahun $=$ masa remaja akhir.

\subsubsection{Perkembangan Emosi Remaja}

Remaja mengalami puncak emosionalitasnya, perkembangan emosi tingkat tinggi. Perkembangan emosi remaja awal yang usianya 12-15 menunjukkan sifat sensitif, emosinya bersifat negatif, mudah tersinggung, marah, sedih, dan murung agresif : melawan, keras kepala, berkelahi, suka menggangu dan lain-lain.

\subsubsection{Pekembangan Moral Remaja}

1) Remaja sudah mampu berperilaku yang tidak hanya mengejar kepuasan fisik saja, tetapi meningkat pada tatanan psikologis (rasa diterima, dihargai, dan penilaian positif dari orang lain).

2) Remaja pada tingkat usia 12-15 ini, belum mampu untuk mengendalikan Diri dan emosi sehingga moral mereka masih dalam kategori belum stabil dan perilaku remaja ini cenderung berdampak pada hal yang negatif.

\subsubsection{Perkembangan Sosial Remaja}

1) Remaja telah mengalami perkembangan kemampuan untuk memahami orang lain dan menjalin persahabatan. Remaja memilih teman yang memiliki sifat dan kualitas psikologis yang relatif sama dengan dirinya, misalnya sama hobi, minat, sikap, nilai-nilai, dan kepribadiannya.

2) Perkembangan sikap yang cukup rawan pada remaja adalah sikap comformity yaitu kecenderungan untuk menyerah dan mengikuti bagaimana teman sebayanya berbuat. Misalnya dalam hal pendapat, pikiran, nilai-nilai, gaya hidup, kebiasaan, kegemaran, keinginan, dan lain-lainnya. Rumini dan sundari (2004)

\section{Metode Penelitian}

\subsection{Jenis Penelitian}

Penelitian ini menggunakan jenis penelitian kualitatif dengan model analisa data yaitu deskriptif analitik. (Kirk dan Miller: 2008)

\subsection{Lokasi Penelitian}

Lokasi penelitian ini adalah SMP Negeri 6 Ambon yang berada di Provinsi Maluku, Kota Ambon Jalan Kakialy Tanah Tinggi Ambon.

\subsection{Sasaran Penelitian:}

Sasaran dalam penelitian ini adalah sekolah SMP Negeri 6 Ambon.

\subsection{Informan Penelitian:}

1. Kepala sekolah SMP Negeri 6 Ambon.

2. Tenaga pendidik dan tenaga kependidikan SMP Negeri 6 Ambon.

3. Siswa - Siswi SMP Negeri 6 Ambon.

4. Orang yang berjualan di kantin, sekolah SMP Negeri 6 Ambon.

\subsection{Teknik Pengumpulan Data:}

Teknik pengumpulan dilakukan dengan observasi, wawancara, dan dokumentasi. (Sugiyono:2010)

\section{Hasil Penelitian dan Pembahasan 4.1 Pembentukan Moralitas Siswa Di Smp Negeri 6 Ambon}

Pembentukan moralitas itu adalah suatu proses atau suatu upanya yang dilakukan oleh pihak-pihak tertentu untuk mencapai tujuan yang dibutukan. Contoh, kedudukan yang diperoleh melalui pendidikan guru, ketua osis, hal-hal ini merupakan cara atau tindakan oleh guru dalam proses belajar mengajar untuk mengubah moralitas siswa yang tidak baik menjadi moral yang baik. Sedangkan moralitas itu cara atau perilaku manusia yang sesuai dengan norma-norma dan aturan yang berlaku di suatu tempat misalnya sekolah, lingkungan masyarakat dan keluarga. (Takaria:2016)

Pembentukan moralitas siswa ini bukan saja menjadi tanggung jawab guru di sekolah tapi ini juga menjadi tanggung jawab kita semua yaitu orang tua, sebagai pendidik pertama di rumah, ketika anak tersebut lahir dan beranjak dewasa. Kemudian lingkungan masyarakat, dimana siswa tersebut tumbuh dan dibesarkan karena lingkungan masyarakat yang tidak baik akan berdampak negatif terhadap perkembangan moral siswa tersebut. Oleh karena itu bagaimana cara yang dipakai oleh guru dan orang tua untuk membentuk perilaku siswa yang tidak baik menjadi baik sesuai dengan norma-norma yang berlaku. (Wairisal:2016)

Globalisasi sangat berpengaruh terhadap perkembangan moral siswa, namun tidak semua siswa terpengaruh oleh dampak negatif globalisasi. Seperti yang diungkapkan oleh A. Tuhehay. S. Pd menurutya pengaruh globalisasi sangat berdampak negatif terhadap moral siswa dan kepada semua generasi Indonesia, karena siswa suka meniru dari 
hal-hal yang tidak baik yang ia lihat melalui internet, siswa dengan mudah meniru hal-hal baru tanpa memikirkan dampak negatifnya terhadap masa depan mereka. (Tuhehay:2016)

Menurut salah satu siswa SMP Negeri 6 Ambon yaitu Artur. Saiya mengungkapkan bahwa, saya sangat setuju kalau globalisasi sangat berdampak negatif terhadap moral siswa, karena era globalisasi sekarang ini sudah sangat canggih. Ada beberapa siswa yang mengupload video dan gambar-gambar porno, hal ini cenderung membuat moral siswa dan karakter anak bangsa bisa saja hancur. (Saiya:2016)

Cara penanganan SMP Negeri 6 Ambon terhadap dampak negatif globalisasi dalam pembentukan moralitas siswa, yaitu:

1) SMP Negeri 6 Ambon melarang siswa membawa HP ke sekolah.

2) Guru harus memiliki kemampuan untuk memahami ilmu pengetahuan yang diajarkan terkait dengan, perkembangan budaya, khususnya menyangkut ilmu pengetahuan, yang sekarang ini tumbuh dengan pesat sehingga pengetahuan yang diajarkan pada siswa pun harus dapat mengikuti perkembangan IPTEK saat ini.

3) Sekolah memberikan himbauan atau penyuluhan kepada siswa tentang perkembangan globalisasi dan dampak negatif dan positif dari globalisasi tersebut dengan cara, bekerja sama dengan pihak-pihak yang mempunyai tugas dan peranan di bidang tersebut.

\subsection{Perkembangan pembentukan moralitas siswa di SMP Negeri 6 Ambon}

Sebagai seorang yang memberikan informasi harus memiliki data yang lengkap dan fakta yang dapat dipertanggung jawabkan, dalam menyampaikan informasi juga harus disertai dengan bukti yang autentik, bukan berupa dugaan, atau karangan belaka dan juga dapat memberikan penjelasan yang dapat dimengerti tentang setiap informasi yang akan disampaikan, baik itu berupa peristiwa-peristiwa nyata maupun berupa ilmu pengetahuan dan teknologi, karena pembelajaran pada dasarnya adalah interaksi antara guru dan siswa dalam proses belajar-mengajar.

Namun berbicara tentang moral anak didik pada saat ini ketika dalam mengikuti pelajaran di kelas, sudah sangat sulit untuk diatur; (yang perlu saya katakan disini) yaitu kondisi sekolah pada tingkat SMP, pada era sekarang ini sangat berdampak buruk bila dilihat dari moral siswa. Ketika guru ada dalam kelas dan sementara belajar saja ada yang berisik (ribut), tawuran (bakupukul) satu dengan yang lain dan yang paling parah lagi ada yang mengeluarkan kata-kata cacian pada hal guru sementara ada dalam kelas. Hal ini bukan saja terjadi di SMP Negeri 6 Ambon tapi saya yakin hal serupa juga pasti dialami oleh sekolah-sekolah yang lain juga.

Kalau di dalam kelas yang ada guru saja terjadi hal sedemikian. Apalagi di luar kelas, dan moral siswa yang paling parah lagi ketika siswa berada di jalan ketika pulang sekolah banyak hal yang mereka lakukan karena tidak dikontrol oleh guru dan orang tua, contohnya seperti tawuran antar sesama pelajar, hal ini tidak lasim lagi bagi guru, orang tua dan masyarakat.( Pattipelohy:2016)

Faktor-faktor yang mengakibatkan perilaku siswa tidak baik terhadap orang lain diantaranya yaitu: (Kesaulya:2016)

1. Keluarga (orang tua di rumah)

2. Lingkungan masyarakat dan pergaulan

3. Pengaruh Globalisasi

4. Pengaruh ekonomi

Menurut Wakasek kesiswaan Ibu, J. Paays. S. Pd. M. Pd. Beliau mengatakan bahwa perilaku buruk yang kita jumpai dari siswa seperti ini harus kita hati-hati dalam mengambil tindakan untuk mengatasi persoalan tersebut karena hal ini adalah pembawaan dari rumah, masyarakat, dan pergaulan oleh karena itu pihak sekolah tidak bisa bekerja sendiri tapi harus bekerja sama dengan orang tua di rumah untuk mengatasi persoalan tersebut. Selain itu Ibu, J. Paays. juga Mengatakan bahwa, tugas saya bukan saja memberikan pelajaran matematika di kelas, namun saya sebagai ketua kesiswaan yang mempunyai tugas untuk menangani persoalan-persoalan yang siswa buat di sekolah SMP Negeri 6 Ambon ini, oleh karena itu saya tau bagaimana keadaan siswa saya. Ada persoalan yang saya jumpai ketika siswa mengeluarkan kata bamaki, ketika ditanyakan dari mana kamu mendengar kata makian ini? siswa tersebut mengatakan bahwa saya dengar dari orang tua dan tetangga sebelah rumah. Kemudian saya bertanya lagi kepada siswa tersebut, apakah kamu tau arti dari perkataan makian yang kamu ucapkan tadi? siswa tersebut menjawab TIDAK TAU. Jawaban yang sangat singkat tapi sangat berbahaya terhadap kehidupan moral siswa tersebut dan masa depannya. (Paays:2016) 
Berdasarkan data yang diperoleh dari informan di atas maka dapat penulis mengatakan bahwa: salah satu faktor yang menyebabkan siswa mengucapkan kata cacian atau bamaki, adalah orang tua, lingkungan masyarakat dan kebiasaan buruk suatu tempat yang suka mengucapkan kata cacian.

Bagaimana dengan kebutuhan siswa contoh buku cetak, uang jajan, uang transpor yang tidak terpenuhi apakah berpengaruh juga terhadap moral siswa dan prestasi siswa tersebut? Ibu, Martje. D. Soselissa S. Pd. Mengatakan bahwa kebutuhan siswa yang tidak terpenuhi sangat berpengaruh pada aspek moral siswa atau anak usia remaja tersebut, karena dalam pergaulan seharihari baik di rumah maupun di sekolah dengan temannya anak tersebut bisa saja minder untuk bergaul karena anak merasa tidak dihargai atau tidak selevel dengan kondisi sosial yang ada pada lingkungan masyarakat maupun di sekolah. Contoh lain yang biasa kita temui, seorang siswa yang tidak mempunyai buku cetak. Hal ini membuat siswa tersebut merasa minder terhadap temantemannya bisa juga terhadap guru mata pelajaran tersebut, hal ini juga sangat berdampak buruk pada prestasi siswa tersebut. (Soselissa:2016)

Selain pendapat yang dikemukakan di atas ada beberapa pendapat lain diantaranya menurut $\mathrm{Ny}$, A. Tuhehay, S. Pd. Mental siswa juga akan berpengaruh, dia akan melakukan berbagai cara untuk memenuhi kebutuhannya. ( Tuhehay:2016)

Menurut pendapat Ny, J. Paays, S. Pd. M. Pd. Saya setuju dengan pendapat yang telah dikemukakan oleh rekan-rekan saya, tapi yang ingin saya melengkapi atau katakan dalam hal kebutuhan siswa ini yaitu, berhubungan dengan uang yang harus menjadi perhatian bagi kita bersama selaku orang tua dan guru di sekolah. Karena hal yang sering saya jumpai ada siswa yang pergi sekolah tidak mendapat uang jajan dari orang tua atau mendapat uang jajan tapi tidak mencukupi kebutuhannya, siswa tersebut merasa minder terhadap teman-temannya, dan untuk memenuhi kebutuhannya dia akan meminta uang dari temanteman dalam konteks ini, sering ada kekerasan atau tawuran yang terjadi antara siswa yang satu dengan siswa yang lain.( Paays:2016)

Apakah keadaan keluarga yang tidak harmonis juga berdampak negatif pada pembentukan moralitas siswa atau anak di sekolah? Menurut pendapat Ibu T. Urlialy, S. Th.
Kesibukan orang tua dalam aktivitas untuk memenuhi kebutuhan keluarga membuat orang tua kehilangan waktu untuk membina anak-anak mereka, tanpa disadari mereka telah melalaikan tugas dan panggilannya untuk membimbing, mengarah, menasehati, dan mendidik anak-anak mereka sesuai dengan kebenaran injil kristus bahkan moral hidup yang sebenarnya. Anak-anak usia remaja cenderung hidup dalam pergaulan bebas, karena tidak adanya kontrol orang tua. Sehingga mereka tidak menyadari ternyata mereka telah merugikan diri mereka sendiri. Orang tua juga salah satu faktor pencetus dalam kecenderungan pada anak, apabila terdapat orang tua yang rumah tangga mereka broken home, dari hal itu anak menjadi tidak bersemangat dalam menjalankan sekolahnya dengan baik. Dari masalah yang di lakukan oleh orang tua merupakan sesuatu hal yang berdampak buruk bagi anak, maka orang tua harus memberikan contoh yang baik bagi anak, agar anak tidak melakukan hal-hal yang tidak diinginkan oleh keluarga. ( Urlialy:2016) Berdasarkan penjelasan para informan di atas, maka dapat dijelaskan bahwa lingkungan sangat berpengaruh terhadap pembentukan moral siswa. Entah lingkungan pergaulan, lingkungan belajar atau lingkungan keluarga.

\subsection{Peranan Guru SMP Negeri 6 Ambon dalam Proses pembentukan Moralitas Siswa}

M.S, Maloky M. Pd.K mengatakan bahwa salah satu pihak yang berperan penting dalam pembentukan moralitas siswa adalah sekolah yang bersangkutan, oleh karena itu SMP Negeri 6 Ambon selalu berusaha untuk menciptakan siswa yang cerdas dan bermoral baik dilingkungan sekolah maupun dilingkungan masyarakat. Upaya pembentukan moralitas siswa yang baik dengan berbagai cara yaitu pihak sekolah melakukan pembinaan secara menyeluruh dan secara pribadi kepada siswa yang bermasalah, dan mengadakan kerja sama dengan pihak lain untuk mengadakan kegiatan penyuluhan dan pembinaan moral terhadap siswa di sekolah. Namun tanggung jawab pembentukan moralitas siswa, bukan saja menjadi tanggung jawab pihak sekolah sendiri. Tapi hal ini merupakan tanggung jawab kita bersama yaitu orang tua di rumah, Gereja, dan masyarakat. ( Maloky:2016)

Berdasarkan data yang diperoleh dari informan di atas menunjukan bahwa dalam proses pembentukan moralitas siswa, orang tua merupakan faktor pertama yang menjadikan siswa 
yang sopan, disiplin, takut akan Tuhan, menghargai dan mengasihi sesama. Namun masyarakat, gereja, dan sekolah juga mempunyai peran penting dalam pembentukan moralitas siswa. Oleh sebab itu sekolah SMP Negeri 6 Ambon selalu bekerja sama dengan lembaga tersebut dalam upaya membentuk moral siswa yang baik.

Pertanyaan selanjutnya apakah moralitas seorang siswa dapat dilihat dari kecerdasan atau prestasi siswa? jawaban yang penulis dapat dari informan yaitu tidak semua siswa yang cerdas mempunyai moral yang baik, begitu juga siswa yang kecerdasannya dikatakan lemah belum tentu moralitasnya buruk. Selain itu moral siswa juga tidak bisa dilihat dari sekolah yang unggul atau mempunyai kualitas yang baik, karena moral seorang siswa yang baik akan terlihat dari karakter dan perilakunya dalam berinteraksi dengan orang lain dalam kehidupan sehari-hari. Oleh sebab itu dapat dikatakan bahwa untuk mengatahui moral seseorang tidak bisa dilihat dari segi apapun dan tidak bisa di tebak namun harus dilihat secara langsung dari karakter dan perilaku siswa tersebut. ( Unaola:2016)

Berdasarkan data yang diberikan oleh informan di atas dapat di simpulkan bahwa moral yang baik bukan dilihat dari kecerdasan dan kepintaran seseorang siswa dalam menunjukan prestasi yang tinggi bagi orang tua dan guru di sekolah. Tapi moral seorang siswa dikatakan baik apabila melakukan hal yang baik sesuai dengan, etika, dan norma.

Adakah teguran atau sangsi bahkan hukuman yang diberikan kepada siswa apabila melakukan pelanggaran, atau tidak mentaati aturan-aturan di SMP Negeri 6 Ambon? informan menjawab; ya ada, dijalan raya saja ada aturannya, apalagi sebuah lembaga pendidikan. siswa sebelum mengenal lembaga pendidikan formal yaitu sekolah, siswa terlebih dahulu mengenal keluarganya (orang tua), lingkungan masyarakat, dan agama. Oleh sebab itu untuk mengatasi moralitas siswa ini, kami selaku pihak sekolah selalu kerja sama dengan orang tua selain itu ada pihak-pihak kami yang mempunyai tanggung jawab khusus untuk menangani persoalan-persoalan tersebut. K. Orno M. Pd.K. Mengatakan, Untuk hal ini perlu adanya penjelasan tentang ke empat pilar tersebut yaitu:

\section{1) Keluarga (orang tua)}

Keluarga adalah tempat ideal mempuyai pendidikan budi pekerti. Didalam keluarga anak akan banyak belajar secara praktis melalui berlatih dan meniru perilaku orang disekitarnya, lebih-lebih meneladani orang tuanya. Melalui pendidikan moral dalam keluarga yang menjadi basis awal perilaku baik dan buruk, anak akan semakin sadar terhadap kehadiran dirinya di dunia. Dalam keluarga normal (harmonis) anak akan cenderung berperilaku positif, sebaliknya pada keluarga yang tidak normal (rusak) anak akan cenderung berperilaku sosial negatif. Karena itu, keluarga merupakan tempat yang sebaik-baiknya untuk melakukan pendidikan sosial dan budi pekerti.

Peran keluarga dalam mengembangkan moral anak sangatlah penting karena hal tersebut berpengaruh pada pembentukan moral dimasa depan. Orang tua sebagai peran utama dalam pembentukan moral. masing-masing orang tua berbeda cara dalam mengajarkan pendidikan moral. Sebagai contoh dalam kehidupan seharihari, orang tua mengikuti dan mengajaak anakanaknya untuk pergi beribada bersama orang tua, supaya sang anak mendapatkan ilmu keagamaan karena hal ini dapat menciptakan etika dan budi pekerti yang baik. Orang tua memakai pakaian yang sopan dengan maksud mangajarkan kepada anak-anaknya untuk berpakain sopan didalam dan di luar rumah untuk memperlihatkan jati diri yang baik. Orang tua mengajarkan bersalaman kepada anak-anaknya sebelum mereka berangkat sekolah ataupun keluar rumah dengan maksud meminta izin (berpamitan) supaya dalam keluarga tercipta keteraturan.

\section{2) Sekolah SMP Negeri 6 Ambon}

Untuk mengambil satu keputusan terkait dengan pelanggaran yang dilakukan oleh siswa di sekolah SMP Negeri 6 Ambon, kami melihat dari pelanggaran apa yang siswa tersebut buat, kemudian sangsi atau hukuman yang diberikan pun secara bertahap, biasanya jika ada kedapatan melakukan pelanggaran contoh mengucapkan kata-kata cacian (bamaki) kami menegur dan melaporkan kepada wali kelas. Bila dikemudian hari siswa tersebut melakukan masalah lagi kami menyerakan kepada kesiswaan kemudian memanggil orang tua murid tersebut, untuk membicarakan masalah yang dilakukan oleh siswa itu. Kemudian siswa diberikan pembinaan oleh kesiswaan dan guru pastoral konseling, namun siswa-siswa ini selalu dikontrol setiap saat oleh pihak sekolah selama ada dalam lingkungan sekolah. Ada juga kami kerja sama dengan orang tua murid untuk menindak lanjuti perkembangan siswa di rumah. Akan tetapi bila dikemudian hari 
siswa tersebut masih melakukan masalah lagi maka siswa tersebut dipulangkan (di skors) kepada orang tuanya selama 3-5 hari dan dikontrol oleh wali kelas atau guru bimbingan konseling. Ketika masa skors telah selesai siswa tersebut kembali ke sekolah, kemudian mendapat pembinaan dari guru yang bersangkutan, setelah itu siswa diantarkan ke dalam kelas untuk mengikuti pelajaran bersama sama dengan teman - temannya.

\section{3) Lingkungan Masyarakat}

Salah satu faktor yang turut memberikan pengaruh dalam terbentuknya sikap seorang siswa adalah lingkungan di mana siswa tersebut berada. Lingkugan ialah suatu yang melingkupi tubuh yang hidup yaitu lingkungan pergaulan. Lingkungan pergaulan adalah faktor yang sangat penting dalam pendidikan moral siswa. Sebaik apapun pembawaan, kepribadian, keluarga, pendidikan yang ditempuh, tanpa didukung oleh lingkungan yang kondusif, maka moral yang baik tidak terbentuk.

Interaksi siswa dengan lingkungan tidak dapat dielakkan, karena siswa membutuhkan teman bermain dan kawan sebaya untuk bisa diajak bicara sebagai bentuk sosialisasi. Sedikit banyak keadaan perilaku dan komunikasi yang diterima akan terekam dibenak siswa. Lingkungan rumah serta lingkungan pergaulan siswa yang jauh dari nilai-nilai agama, lambat laun akan dapat melunturkan pendidikan agama khususnya pendidikan etika dan moral yang telah ditanamkan baik dirumah maupun di sekolah.

Kemajuan ilmu pengetahuan dan teknologi (IPTEK) telah menciptakan perubahan besar dalam kehidupan ini. Televisi atau media massa lain yang lahir dari kemajuan IPTEK telah banyak memberikan dampak yang negatif kepada perkembangan siswa, terutama dalam pembentukan pribadi dan karakter siswa. Sekian banyak dari tayangan televisi, hanya sedikit yang sifatnya mendidik dan terbebas dari hal yang berdampak negatif, sebagian besar lainnya justru memberi pengaruh yang buruk bagi para siswa.

\section{3) Gereja}

Gereja adalah tubuh Kristus yang saling melengkapi dan saling membangun untuk mencapai suatu tujuan dan percaya kepada Yesus Kristus. Dalam gereja tidaklah terlepas dari pengajaran, pendidikan dan bimbingan, baik kepada orang tua, penatua, pemuda, remaja, maupun anak-anak. Dalam hal ini, gereja selalu aktif dalam pembentukan moral anak bangsa. Pendidikan kepada remaja sangatlah penting. Gereja harus mampu membentuk mentalitasnya dari sejak anak-anak. "Biarkan anak-anak datang kepada-Ku, jangan menghalang-halangi mereka, sebab orang-orang seperti itulah yang empunya Kerajaan Allah" (Mrk. 10:14, Mat. 19:14, Luk. 18:16). Ayat ini mengingatkan kita sebagai dasar Alkitab dari pelaksanaan pendidikan anak. Sebagaimana Yesus menghargai dan menerima anak-anak, demikian pula gereja menghargai dan menerima mereka melalui pendidikan/pengajaran untuk membentuk moral anak dari masa lalu, masa kini dan masa yang akan datang. (Orno:2016)

Berdasarkan data yang diperoleh dari informan di atas menunjukan bahwa, ada sangsi atau hukuman dari pihak sekolah kepada setiap siswa yang tidak mentaati aturan, yang ada dalam lembaga pendidikan tersebut. Namun sangsi atau hukuman itu dilihat dari pelanggaran yang dilakukan oleh siswa tersebut.

Upaya-upaya yang dilakukan oleh pihak sekolah untuk mengatasi permasalahan yang dilakukan siswa, dengan cara pihak sekolah melibatkan orang tua dalam membina siswa tersebut. Dengan adanya sangsi/hukuman yang diberikan kepada siswa, dengan harapan agar kesalahan yang dilakukan oleh siswa tidak akan diulangi lagi. Siswa harus taat pada aturan-aturan yang sudah ditanamkan oleh pihak sekolah dan orang tua. Namun bukan saja sekolah dan orang tua yang mempunyai tugas untuk membentuk moral siswa, namun gereja dan lingkungan masyarakat pun turut terlibat membentuk moral siswa, agar perilaku siswa tidak mudah di goyahkan oleh pengaruh apapun. Orang tua, lingkungan masyarakat dan gereja harus menjadi contoh yang baik bagi siswa tersebut.

\subsection{Implikasi PAK}

SMP Negeri 6 Ambon merupakan lembaga pendidikan formal yang telah di bentuk, sebagai lembaga pendidikan yang didalamya PAK berperan penting untuk membentuk moral siswa, harus berfungsi dengan baik. Hubungan antara guru sebagai pendidik dan siswa sebagai peserta didik dalam proses PAK, guru harus menciptakan suasana yang baik. Oleh karena itu menjadi seorang guru bukalah suatu hal yang mudah, sebab pekerjaan seorang guru membutuhkan pengetahuan yang luas dan keahlian di bidangnya untuk mengarahkan moral siswa ke arah yang lebih 
baik. Apabila semua pengetahuan dan keahlian dikuasai, dilaksanakan dengan baik maka guru tersebut akan menjadi guru yang profesional. Menjadi seorang guru bukan hanya terpanggil atas panggialan profesinya saja tetapi lebih dari itu, terpanggil sebagai seorang rasul, seorang gembala, dan pengajar. Itu berarti tugas guru adalah tugas yang paling mulia, karena itu sosok guru yang baik patut mencontohi teladan Sang Guru Agung yaitu Yesus. Yesus memang tidak menjalani pendidikan guru seperti yang ada sekarang ini, tetapi profesi Yesus sebagai seorang guru itu terlihat dalam seluruh pekerjaan pelayanannya. Sehingga Ia disebut guru yang agug atau Rabbi.

Ada tiga hal yang menunjukan bahwa Yesus adalah guru adalah:

1. Karena hal ini diakui oleh banyak orang.

2. Demikian disebutkan oleh para penulis kitab Injil.

3. Dalam semua kitab Injil digambarkan Yesus adalah pengajar.

Dengan demikian faktor pembentuk moral siswa adalah tanggung jawab PAK, dalam hal ini guru yang memiliki sejumlah kompetensi ilmu pengetahuan terlebih adalah talenta yang Allah. anugrahkan kepadanya. Yaitu talenta untuk melayani umatnya, seperti Yesus adalah anak Allah yang menjalankan misiNya di dunia, dengan cara mengajar para murid dan umatnya, untuk mengenal siapa sesungguhnya Allah itu yang mengajar orang untuk bergaul dengan Allah, dan mencapai transparansi iman, dan dengan sendirinya meningkatkan kualitas hidup mereka yang percaya kepada Allah. Yesus sebagai seorang guru agung yang patut untuk diteladani, nampak pada aspek karakter, kompetensi dan karisma. Dalam hal ini dapat kita lihat, di mana Allah dikatakan demikian karena jangkauan berpikir Yesus jauh ke depan, dalam berbicara maupun mengajar Ia selalu berbicara tentang masa depan.

Integritas yang tinggi juga merupakan hal yang memiliki kaitan, dikarenakan semua katakata Yesus selalu sinkron atau selaras, sejalan dengan perbuatannya. Yesus sendiri berani mengambil resiko atas pelayanannya serta kreatif dan inovatif, Yesus selalu mencari dan menemukan berbagai cara dalam mengajar serta menghadapi berbagai situasi pelayanan dengan spirit yang kuat dan Ia berupaya menciptakan komunikasi dengan siapa saja. Aspek kompetensi membutuhkan keterampilan dan terlatih, Yesus memilikinya sejak kelahiranNya, Ia terlatih untuk menderita baik itu mulai dari kelahiranNya di kandang betlehem, pengungsian di mesir bahkan sampai pada kematianNya. Disisi lain Yesus sejak berusia 12 tahun, Yesus memperoleh pendidikan di bait Allah dan Ia selalu mengambil hikmah. Serta makna dari tiap-tiap pengalamanNya, sehingga Ia membangun kekuatan spiritual dari intelektual-Nya. Yesus adalah tipe pengajar yang selalu memiliki keinginan-keinginan dan spirit untuk belajar. Aspek yang terakhir adalah kharisma. Kharisma yang dimiliki Yesus yang sejak lahir dari spiritualitas-Nya mendatangkan hikmat bagi diriNya dan bagi orang lain .hal itu nampak melalui perkataan dan perbuatan ( pengambilan keputusan), Ia mampu bersimpati dan berempati terhadap orang lain dalam setiap persoalan manusia, tidak sebatas menghakimi tetapi sebaliknya Ia membimbing serta mendampingi orang untuk sadar akan kesalahannya serta berupaya memperbaiaki diri. (Supeno:1995)

Dalam menyampaikan injil kebenaran Allah banyak hal yang Yesus ajarkan kepada murid-murid dan juga orang-orang yang mendengarkan firman Allah. Salah satunya yaitu, Yesus mengajar, membimbing serta mendampingi Zakheus untuk mengubah hidupnya yang berdosa, karena Zakheus adalah seorang pemungut cukai yang kaya dan mempunyai moral yang kurang baik.Yesus pergi dari jauh sampai di kota Yerikho, Yesus berjalan dan melihat Zakheus sedang memanjat pohon arah, karena saat Ia tidak berhasil menerobos kerumunan orang, karena keterbatasan fisiknya dan kemudian nekat memanjat pohon ara untuk melihat Yesus, hati Zakheus sangat bergembira, Yesus melihat dan menyapa bahkan menumpang di rumah Zakheus, segera turun dan Zakheus menerima Yesus dengan sukacita, untuk menyelamatkan Zakheus dari dosa dan membentuk moral Zakheus menjadi baik. Ketika itu Zakheus sadar akan hidupnya yang semula hidup dalam kemewahan dan memeras orang miskin, Ia berbagi harta miliknya menjadi tidak berarti, setengah hartanya akan diberikan kepada orang miskin dan orang yang pernah Ia peras dan mendapat ganti empat kali limpat. Seluruh hidup Zakheus sekejap berubah dan semua ketakutan serta kecemasanya hilang. Sebab Yesus pergi dari jauh ke kota Yerikho untuk mencari dan menyelamatkan Zakheus yang hilang. Maka kata Yesus kepadanya hari ini telah terjadi keselamatan kepada rumah ini, sebab anak manusia datang untuk mencari dan 
menyelamatkan yang hilang. Inilah juga yang menjadi kunci iman kristen. Sebab bukan kita yang mencari Allah, namun Allah sendirilah yang mencari dan menyelamatkan kita dari dosa. ( Lukas 19:1-10).

Sekolah merupakan salah satu lembaga Pendidikan yang dilakukan oleh pemerintah secara berencana, terarah, dan terus menerus untuk membentuk moral setiap anak bangsa. Yang didalamnya yaitu guru difungsikan, untuk membina dan mendidik siswa dalam membentuk moral yang baik. Sehingga dapat mengembangkan kepribadian siswa kedepan agar moral siswa dapat dibetuk sesuai dengan ajaran Yesus yang sudah ditanamkan bagi umat-Nya, bahwa Yesus adalah juruselamat dunia dan dirinya supaya Ia mendapat hidup dengan mengasihi dan mengabdi bagi sesama dalam segala segi kehidupan.

Dengan demikian sekolah adalah salah satu tugas pelayanan yang diberikan Allah kepada Yesus Kristus dan kini oleh umatnya yaitu guru di sekolah, orang tua dan gereja untuk membina, mendidik mengasuh, melatih dan melengkapi semua kekurangan siswa yang belum terpenuhi dengan baik untuk memasyurkan injil di dunia dengan dukungan iman, pengharapan dan kasih melalui hidup.

\section{Simpulan}

Pembentukan moralitas adalah cara membentuk perilaku seseorang yang berdampak negatif menjadi perilaku yang positif. Salah satunya adalah pembentukan moralitas siswa SMP Negeri 6 Ambon. Masalah moralitas siswa SMP Negeri 6 Ambon adalah ada siswa yang mengeluarkan kata - kata cacian terhadap teman dilingkungan sekolah pada saat berkomunikasi dan mengikuti pelajaran di kelas, siswa kurang menghargai guru, terjadi perkelahian antara siswa dengan siswa di lingkungan sekolah, dan ada siswa yang salah mempergunakan HP dengan baik tapi mempergunakan untuk mengupload gambargambar porno.

Upaya - upaya dari pihak sekolah untuk mengatasi masalah moralitas siswa yaitu:

1. Wali kelas melakukan pembinaan kepada siswa yang bermasalah.

2. Wali kelas bekerja sama dengan guru Bimbingan Konseling untuk melakukan bimbingan dan pembinaan kepada siswa yang bermasalah.
3. Guru kesiswaan, guru bimbingan konseling dan wali kelas bertanggung jawab sepenuhnya untuk membentuk moralitas siswa yang bermasalah menjadi moralitas yang baik, dengan melibatkan orang tua untuk mengontrol perkembangan siswa di rumah.

4. Sekolah memberikan pembinaan secara menyeluruh kepada siswa, pada waktu ibada OSIS dan SMP Negeri 6 Ambon bekerja sama dengan pihak Gereja dan Polri untuk melakukan kegiatan penyuluhan pembinaan moral dan iman kepada siswa di sekolah.

Upaya pembentukan moralitas siswa merupakan tanggung jawab bersama antara sekolah, orang tua, lingkungan masyarakat dan gereja.

\section{Saran}

1. Kepada kepala sekolah SMP Negeri 6 Ambon, para dewan guru, dan pegawai untuk tetap bekerja keras dan tetap berusaha menemukan solusi yang baik dalam upaya meningkatkan moralitas siswa SMP Negeri 6 Ambon.

2. Kepada orang tua, Pembentukan moral siswa bukan hanya menjadi tanggung jawab sekolah tetapi menjadi tanggung jawab orang tua, gereja dan masyarakat. Karena itu kepada pihak - pihak yang selama ini belum berperan secara maksimal dalam pembentukan moralitas siswa, diharapkan dapat berperan dengan baik agar kedepan siswa menjadi pribadi yang baik dalam keluarga dan masyarakat dengan prestasi dan masa depan yang cemerlang

3. Kepada semua siswa SMP Negeri 6 Ambon, jangan lalai dan bosan dalam menerima didikan yang diajarkan oleh orang tua, guru di sekolah, dan gereja, karena ajaran dan didikan yang diberikan sangat berguna bagi masa depan.

\section{Ucapan Terima Kasih}

Pada kesempatan ini, terimakasih saya ucapkan kepada redaktur yang telah memberikan masukan yang berharga sehingga tulisan ini dapat disajikan di jurnal Institutio. Terimakasih juga saya ucapkan kepada seluruh dewan redaksi jurnal Institutio yang sudah memberikan ruang diskusi. Semoga bantuan dan dukungannya mendapatkan balasan yang sebanyak-banyaknya dari Tuhan kita Yesus Kristus, Amin. 


\section{Pustaka Acuan}

Budiningsih, C.Asri., 2014, Pembelajaran Moral, Jakarta: PT. Rineka Cipta.

Barnawi, dan M. Arifin., 2014, Strategi dan Kebijakan Pembelajaran Pendidikan Karakter, Jogjakarta: Ar-Ruzz Media.

Burhan, H. M. Bungin., 2008, Penelitian Kualitatif, Jakarta: Kencana Prenada Media Group.

Burhanuddin, H. Salam,. 2012, Etika Individual Pola Dasar Filsafat Moral, Jakarta: Rineka Cipta.

Budiningsih, C. Asri., 2014, Pembelajaran Moral, Jakarta: PT Rineka Cipta.

Edison, A. Jamli., 2005, Pendidikan

Kewarganagaraan, Jakarta: PT Intan

Pariwara.

Notonagoro., 2010, Pendidikan

Kewarganegaraan, Untuk SMP Kelas VII,

Klaten: PT. Intan Pariwara.

Purwa, Hardiwardoyo, Al., 1990, Moral dan Masalahnya, Yogyakarta: PT Kanisius.

Rumini Sri. Dan Sundari Siti., 2004, Psikologi Remaja, Jakarta: Rineka Cipta.

Syaiful Bahri Djamah., 2005, Guru dan Anak didik dalam Interaksi Edukatif ( Suatu Pendekatan Teoritis Psikologis), Jakarta: Rineka Cipta.

Soelaeman, M. I. Dan Adler,. 2007, Pengantar Pendidikan Moral, Jakarta: Universitas Terbuka.

Siron dan Supeno. H., 1995, Potret Guru, Jakarta: Pustaka Harapan.

Sopacua, S., 2007, Materi Ajar Profesi Keguruan PAK (tidak dipublikasikan), Ambon: STAKPN.

Sugiyono., 2010, Memahami Penelitian Kualitatif, Bandung: CV. Alfabeta.

Salamor Rainer., 2013, Ibadah Dan Pembinaan Moral (Studi Persepsi Pada Angkatan Mudah GPM Daerah Pulau Ambon, Cabang Elim 4, Ranting Syaloom 3 Dan Implikasi $P A K)$, Ambon: SKRIPSI, Jurusan Pendidikan Agama Kristen, STAKPN.

Sulilatu, Susana., 2012, Peranan Guru PAK Dalam Membentuk Moralitas Siswa Pada SMA I Kristen Saparua (Khusus Kls XII IPS), Ambon: SKRIPSI, Jurusan Pendidikan Agama Kristen, STAKPN.

Latupeirissa, Esther., 2012, Komunikasi Orang Tua Terhadap Pembentukan Moralitas Remaja Dan Implikasinya. (Studi Di Jemaat GPM Poka Klasis Pulau Ambon), Ambon:
SKRIPSI, Jurusan Pendidikan Agama Kristen, STAKPN.

Kamus Besar Bahasa Indonesia ( KBBI )., 1996, Jakarta: Balai Pustaka. 